\title{
LEARNING MODEL OF DISASTER RESPONSE AS A PHYSICAL ACTIVITY IN ELEMENTARY SCHOOL STUDENTS
}

\author{
Adi Sumarsono \\ Universitas Musamus Merauke, Papua, Indonesia \\ Email: adi@unmus.ac.id \\ Algiranto \\ Universitas Musamus Merauke, Papua, Indonesia \\ Email: algiranto20@gmail.com
}

DOI: 10.35445/alishlah.v11i2.132

Accepted: June $14^{\text {th }}, 2019$. Approved: November $11^{\text {th }}, 2019$. Published: December $30^{\text {th }}, 2019$

\begin{abstract}
This study aims to produce a type of game through physical activities that are in activies that are in accordance with physical education learning materials in elementary schools. This research also test the effectivenes of the products that have been produced. This development research methods refers to the Borg and Gall development step which consistes of ten development steps. The result of study are the creation of a type of game with the name og the name the game disaster response. The specifications of this game are the types of games that are carried out in the form of physical activities in which there are fundamental movements (locootor, non locomotor and manipulative motion). These three types of motion correspond to physical education materials in elementery schools. The results of this development product are saved in the form of VCD tutorial videos. The effectiveness test of this product was teted on two different schools and analyzed using a t test of significances 0,5 state that series of disarter response games are effective and appropriate to be used as physical education learning for elementary school students. Increased effectiveness is stated in the standard Gain which is in the category of "medium". Throught this disaster response game it can be used as basic motion learning in elementary schools as well as providing preliminary material about emergency rescue efforts in the event of a natural disaster.
\end{abstract}

Keyword: Game, Physical Activity 
Al-Ishlah: Jurnal Pendidikan - ISSN: 2087-9490 (p); 2597-940X (e)

Vol. 11, No. 2 (2019)

\title{
MODEL PERMAINAN TANGGAP BENCANA SEBAGAI AKTIVITAS JASMANI PADA SISWA SEKOLAH DASAR
}

\begin{abstract}
Abstrak
Penelitian ini bertujuan untuk menghasilkan jenis permainan melalui aktivitas jasmani yang sesuai dengan materi pelajaran Pendidikan Jasmani di sekolah dasar. Penelitian ini juga menguji efektivitas produk yang telah dihasilkan. Metode penelitian pengembangan ini mengacu pada langkah pengembangan Borg \& Gall yang terdiri atas sepuluh langkah pengembangan. Hasil penelitian ini adalah terciptanya jenis permainan dengan nama permainan tanggap bencana. Spesifikasi permainan ini adalah jenis permainan yang dilakukan dalam bentuk aktivitas jasmani yang di dalamnya terdapat gerak dasar fundamental (gerak lokomotor, nonlokomotor, dan gerak manipulatif). Ketiga jenis gerak ini sesuai dengan materi pendidikan jasmani di sekolah dasar. Hasil dari produk pengembangan ini disimpan dalam bentuk video tutorial VCD. Efektivitas produk ini diujicoba pada dua sekolah yang berbeda dan dianalisis menggunakan uji $t$ signifikansi 0,5 yang meyatakan bahwa rangkaian permainan tanggap bencana efektif dan sesuai digunakan sebagai pelajaran Pendidikan Jasmani siswa sekolah dasar. Peningkatan efektivitas dinyatakan dalam Gain Standart yang berada pada kategori "sedang". Permainan tanggap bencana ini dapat digunakan sebagai pembelajaran gerak dasar di sekolah dasar sekaligus pemberian materi awal tentang upaya penyelamatan darurat jika terjadi bencana alam.
\end{abstract}

Kata Kunci: Permainan, Aktivitas Jasmani

\section{PENDAHULUAN}

Indonesia adalah negara yang berbentuk republik dan terbentang dari daerah Sabang hingga Merauke. Terbentangnya wilayah ini terdiri atas banyak pulau yang dipisahkan oleh laut. Wilayah luas Indonesia sangat rentan dari bencana alam. Badan Nasional Penanggulangan Bencana (BNPB) menyampaikan bahwa ada 2.175 kejadian bencana sejak tahun 2017 (Putri, 2018). Berdasarkan pernyataan tersebut, warga negara Indonesia diharuskan tanggap terhadap informasi bencana termasuk penanggulangan dalam menghadapinya. Salah satu pemberian informasi dapat diberikan melalui dunia pendidikan (sekolah). Dunia sekolah merupakan tempat belajar yang efektif untuk menanamkan nilai positif kepada siswa. 
Al-Ishlah: Jurnal Pendidikan - ISSN: $2087-9490$ (p); 2597-940X (e)

Vol. 11, No. 2 (2019)

Mempersiapkan generasi yang dapat memberi kontribusi bagi daerah tidak dimulai ketika berada dalam jenjang pendidikan tinggi. Akan tetapi, lebih efektif jika dimulai sejak anak mengecap pendidikan dasar. Saat anak duduk di bangku $\mathrm{SD}$, seharusnya telah diperkenalkan akan peran mereka sejak dini sehingga muncul rasa cinta kepada lingkungan dan daerah tempat tinggal mereka (Kuwahara, 2012; UNESCO, 2014; Sianturi, 2018). Pada usia sekolah dasar, fokus perhatian anak adalah dukungan dalam peran kelompok yang lebih dominan dalam lingkungan pertemanan. Hal ini dapat dilihat dari usaha penyesuaian diri terhadap siswa lainnya (Rustiana, 2013). Perkembangan pada masa yang akan datang juga akan dipengaruhi oleh stimulasi bermakna yang diberikan saat usia pendidikan dasar. Pendidikan pada awal kehidupan anak merupakan masa yang paling tepat dalam memberikan dorongan guna perkembangan mereka secara optimal. Pada masa perkembangan aspek moral, siswa dapat diarahkan kepada hal yang lebih positif. Anak usia sekolah secara spontan dapat mengekspresikan berbagai pengalaman dalam bentuk kegiatan jasmani (Winarni, 2011). Stimulasi yang diberikan oleh orang dewasa akan mempengaruhi anak pada masa yang akan datang. Oleh karena itu, diperlukan upaya yang mampu memfasilitasi anak dalam tumbuh kembangnya berupa kegiatan pendidikan yang disesuaikan dengan minat, usia, serta kebutuhannya.

Pendidikan di sekolah dasar merupakan pendidikan yang digunakan dalam memberikan bekal pendidikan dasar kepada setiap siswa. Pendidikan dasar yang disampaikan kepada siswa merupakan pembekalan dini sebagai usaha pencegahan terjadinya bencana alam. Melalui pendidikan dasar dapat diterapkan materi tanggap bencana sedini mungkin (Rosali, 2016). Hal ini didasarkan pada Kurikulum 2013 di sekolah dasar yang diberlakukan berupa kurikulum tematik. Kurikulum tematik atau kurikulum berbasis tema yang integratif memberikan peluang kepada guru untuk mengajarkan materi yang berkaitan dengan keadaan alam sekitar. Misalnya, pada materi bertema lingkungan siswa mempelajari peristiwa alam, cara menjaga kelestarian lingkungan, dan berbagai peristiwa lainnya dalam kehidupan. Sementara itu, pada usia sekolah dasar, siswa sangat suka dengan aktivitas bermain.

Berdasarkan latar belakang tersebut, melalui penelitian ini, dibuat, dirancang, dan dikembangkan suatu produk pembelajaran berupa permainan yang tersusun dan terstruktur dengan tujuan mengenalkan jenis bencana alam sedini mungkin. Jika sudah mengenal, siswa akan mengetahui cara menghadapi bencana yang terjadi. Dalam permainanyang dirancang ini juga diberikan pendidikan cara dan upaya menjaga alam supaya tidak terjadi bencana alam. Permainan yang disusun secara terstruktur dan produk yang dihasilkan disimpan dalam bentuk VCD sehingga dapat diajarkan kepada siswa melalui pembelajaran interaktif di kelas. Dengan harapan, setelah siswa melihat video tersebut, mereka dapat 
Al-Ishlah: Jurnal Pendidikan - ISSN: $2087-9490$ (p); 2597-940X (e)

Vol. 11, No. 2 (2019)

mempraktikkannya di luar kelas dalam bentuk aktivitas jasmani yang menyenangkan.

Setiap manusia melakukan tugas gerak fisik yang terstruktur. Gerakan manusia tersebut disesuaikan dengan kebutuhan gerak. Aktivitas jasmani adalah kebutuhan mendasar dari manusia sebagai makluk hidup. Sejak masih dalam kandungan sampai manusia tua, hidup selalu dilakukan dengan bergerak untuk produktif. Bergerak memberikan tanda bahwa manusia masih hidup. Manfaat dari bergerak sangat banyak untuk manusia, salah satunya untuk kelancaran kerja otak. Aktivitas fisik sangat baik untuk kesehatan manusia, di antaranya adalah perkembangan otak (Perez, Pedro, Bush, \& Michael, 2013). Secara fisiologis, kemampuan otak akan berangsur bekerja optimal dengan melakukan aktivitas gerak jasmani. Aktivitas jasmani akan memacu perkembangan otak melalui pemenuhan kebutuhan energi di otak berupa darah dan oksigen (Sukadiyanto \& Muluk, 2010).

Aktivitas jasmani tidak terpisahkan dari anak. Setiap hari, anak usia sekolah akan tumbuh dan berkembang melalaui aktivitas jasmani. Aktivitas jasmani pada anak dapat dilakukan di rumah dan juga di sekolah (Suharjana, 2013). Jenis gerak yang dilakukan anak di sekolah diarahkan pada tiga domain, yaitu domain psikomotor, pengetahuan, dan afektif atau sikap siswa (Graham, Hale, \& Parker, 2009). Sementara, aktivitas gerak di rumah mencakup kegiatan bermain atau aktivitas lainnya yang mengandung unsur jasmani. Aktivitas yang disukai anak pada usia sekolah, di mana pun, adalah bermain.

Aktivitas jasmani yang dilakukan dengan rancangan yang terstruktur kadang kala bertolak belakang dengan tujuan permainan tersebut. Aktivitas jasmani yang terstruktur belum tentu berdampak positif bagi perkembangan anak. Permainan terstruktur yang banyak mengandung peraturan tidak berdampak baik bagi perkembangan anak. Aktivitas jasmani yang baik untuk perkambangan anak adalah melalui aktivitas bermain seusianya (Brockman, Fox, \& R, 2011). Aktivitas anak yang dilakukan melalui kegiatan bermain dapat menambah kecakapan sebagai bekal untuk mengarungi hidup pada usia dewasa kelak. Aktivitas jasmani yang dilakukan melalui kegiatan bermaian di sekolah dapat difasilitasi oleh guru Pendidikan Jasmani dengan menekankan aktivitas gerak yang menyenangkan.

Indonesia adalah negara yang sering mengalami bencana alam. Sebagai negara yang beriklim tropis, Indonesia mempunyai 2 musim, yaitu kemarau dan hujan, yang dapat menyebabkan Indonesia rentan tertimpa bencana alam. Kerentanan ini diyakini semakin meningkat dengan perubahan iklim global dan laju jumlah penduduk beserta pluralitas yang ada (Suhada, Khairuddin, \& Dirmansyah, 2014). Akibat terjadinya bencana alam, tabungan dan aset yang dikumpulkan selama bertahun-tahun dapat lenyap dalam hitungan detik. 
Al-Ishlah: Jurnal Pendidikan - ISSN: $2087-9490$ (p); 2597-940X (e)

Vol. 11, No. 2 (2019)

Jenis bencana bisa dikelompokkan menjadi dua, yaitu hidrometeorologis (banjir, tanah longsor, gelombang pasang/abrasi, kebakaran hutan dan lahan, kekeringan, dan angin puting beliung) dan geologis (gempa bumi, tsunami, dan letusan gunung api) (Amri, 2017). Dari data Badan Nasional Penanggulangan Bencana tahun 2017 dalam lima belas tahun terakhir, antara 2002-2016, tampak bahwa jumlah bencana di Indonesia meningkat hampir dua puluh kali lipat.

Bencana yang terjadi hampir setiap waktu seharusnya dapat diminimalisasi sejak dini. Kesadaran masyarakat dalam memahami alam dapat diturunkan melalui program pendidikan di sekolah. Pendidikan bencana sangat efektif jika diajarkan sejak dini. Anak usia dini yang masih belum mengerti yang harus dilakukan saat terjadi bencana secara tidak terduga harus diberi pemahaman (Desfandi, 2014). Pendidikan terkait kebencanaan di sekolah dapat diterapkan melalui berbagai tahapan, seperti pengetahuan pendalaman materi, keputusan, dan tindakan yang harus dilakukan setiap individu ketika bencana terjadi (Susanti, Sari, Milfayeety \& Dirmansyah, 2014). Keberadaan sekolah sangat dominan dalam memberikan edukasi tentang hal ini pada masyarakat terdidik sebagai bentuk mitigasi. Sekolah memiliki peran strategis dalam mendidik dan memberikan materi mitigasi bencana sejak dini, mulai dari SD, SMP, dan SMA (Rosali, 2016).

Untuk meminimalkan risiko atau kerugian bagi manusia, perlu pengetahuan, pemahaman, kesiapsiagaan keterampilan mencegah, mendeteksi, dan mengantisipasi secara lebih dini tentang berbagai macam bencana, khususnya di tempat-tempat yang memang rawan terhadap bencana alam (Mantasia \& Jaya, 2016). Maka, Materi kebencanaan dapat diajarkan di sekolah melalui pemahaman dan pengetahuan. Pengejawantahan antara pengetahuan yang diperoleh di kelas dengan sikap dan keterampilan yang harus dikembangkan dapat dimiliki siswa berupa nilai-nilai budi pekerti luhur yang telah menjadi budaya dalam kehidupan sosial sekolah (Dahliya, 2017). Paradigma penanggulangan bencana harus berubah. Dahulu, penanggulangan di titikberatkan pada fase pascabencana (tanggap darurat). Namun, saat ini, penanggulangan lebih diprioritaskan pada fase prabencana (kesiap siagaan) yang bertujuan untuk mengurangi risiko bencana (Suryani, Sari, \& Milfayetty, 2014). Pembelajaran di sekolah dapat dilakukan dengan memberikan pengalaman kepada siswa. Pengalaman akan bencana alam yang berulang dapat membuat seseorang lebih siap (Lesmana \& Purborini, 2015). Dengan demikian, pendidikan yang dilakukan pada siswa sekolah dapat membantu meminimalisasi korban bencana.

Stimulasi dalam mengenalkan kebencanaan akan efektif jika dilakukan pada masa sekolah. Siswa yang sudah siap menerima materi pelajaran dapat diberikan materi pengenalan tentang kebencanaan serta upaya yang harus dilakukan dalam mengahadapi bencana. Materi tersebut dapat diberikan melalui aktivitas gerak, seperti kegiatan bermain. Kegiatan bermain dikreasikan dalam 
Al-Ishlah: Jurnal Pendidikan - ISSN: $2087-9490$ (p); 2597-940X (e)

Vol. 11, No. 2 (2019)

bentuk gerak melalui penahapan yang terstruktur akan membuat siswa dengan senang hati melakukannya. Melalui aktivitas permainan inilah siswa akan merasa nyaman bergerak walaupun diarahkan pada materi yang disesuaikan dengan kurikulum di sekolah dasar.

Permainan yang mengandung materi pengenalan tentang bencana ini bisa diintegrasikan dengan Pendidikan Jasmani di sekolah. Pendidikan Jasmani di sekolah tidak selalu harus berorientasi pada konsep dan teknik berolahraga. Upaya dalam menambah perbendaharaan gerak siswa dapat dilakukan melalui berbagai jenis permainan. Melalui permainan yang sudah ditentukan oleh guru dapat mencapai tujuan pendidikan secara keseluruhan. Modifikasi dalam mengajarkan materi olahraga dalam Pendidikan Jasmani dapat dilakukan melalui modifikasi ukuran lapangan, peralatan, dan peraturan (Margono, 2012). "Basic game is single every human instinct to compete and archieve a science of statisfaction that complex, the basis of this game is also used to reach and encourage the development and introduction of the sport" (Cristohper \& Ludy, 2009). Dengan kata lain, dasar permainan adalah naluri tunggal setiap manusia untuk besaing dan mencapai kepuasan naluri yang kompleks. Dasar permainan ini juga digunakan untuk mencapai dan menyemangati pengembangan dan pengenalan olahraga. Selain itu, I.E (2014) mengatakan bahwa permainan adalah kegiatan yang disusun sedemikian rupa yang merupakan aktualisasi diri terhadap kegiatan yang disukai, melalui permainan dapat membangun diri, mengenal, dan juga mengekspresikan diri dalam proses belajar. Dengan demikian, bebarapa tujuan pembelajaran dapat tercapai. Untuk itu, dapat disimpulkan bahwa yang dimaksud dengan permainan adalah sarana yang dilakukan untuk aktivitas bermain, di dalamnya terdapat peraturan yang sudah disepakati oleh anggota yang melakukan aktivitas tersebut.

Aktivitas gerak siswa sekolah dasar sangat berpengaruh pada kemajuan kualitas geraknya. Hal ini sesuai dengan yang disampaikan oleh Sumarsono (2017), bahwa prevelensi gerak anak sangat dipengaruhi oleh jenis gerak dan usia siswa yang dilakukan sedini mungkin. Kualitas gerak siswa pada usia dini kelak akan mempengaruhi kualitas gerak pada masa dewasa. Aktivitas jasmani yang disusun dalam bentuk permainan yang menyenangkan dapat menjadi solusi dalam proses pembelajaran di sekolah. Pemahaman permainan dan sekaligus bencana alam akan membuat siswa menjadi individu yang selalu waspada dalam menjalani kehidupan. Benacana alam merupakan hal yang tidak diundang. Kedatangannya selalu memberikan pengorbanan yang mendalam, baik jiwa maupun harta benda. Akan tetapi, dengan kesiapan tanggap darurat saat terjadi bencana dapat meminimalisasi jumlah korban. Melalui pengembangan yang dilakukan pada pelajaran Pendidikan Jasmani yang memaksimalkan peran guru dapat memberikan solusi pencegahan dini, yaitu pemberian materi tanggap darurat 
Al-Ishlah: Jurnal Pendidikan - ISSN: 2087-949o (p); 2597-940X (e)

Vol. 11, No. 2 (2019)

kepada siswa agar lebih waspada terhadap bahaya bencana alam yang sewaktuwaktu dapat terjadi.

\section{METODE PENELITIAN}

Metode dalam penelitian ini adalah penelitian dan pengembangan (research and development $[\mathrm{R} \& \mathrm{D}]$ ). Pengertian R\&D menurut Sugiyono (2010) adalah metode penelitian yang digunakan untuk menghasilkan produk tertentu dan meguji keefektivan produk tersebut. Penelitian pengembangan model pengenalan bencana berbasis permainan merupakan penelitian untuk mencari, menemukan, merumuskan, memperbaiki, mengembangkan, menghasilkan, dan menguji keefektivan produk. Spesifikasi produk yang dihasilkan dalam penelitian ini adalah jenis dan ragam aktivitas jasmani yang dilakukan dalam prosedur permainan untuk mengenalkan dan mengatasi bencana alam bagi siswa sekolah dasar.

Instrumen dalam mengumpulkan data pada penelitian ini adalah angket. Validasi produk yang berupa permainan aktivitas jasmani sebagai usaha tanggap bencana dilakukan oleh ahli bidang permainan usia dini dan ahli bidang mitigasi bencana. Validasi dilakukan dengan mengisi angket tentang produk yang dibuat, termasuk memberikan saran dan masukan terhadap produk yang dikembangkan. Analisis data yang dilakukan oleh ahli permainan dan praktisi sekolah dasar dikatakan valid jika telah berada pada tingkat kategori validitas sesuai.

\section{HASIL DAN PEMBAHASAN}

Penelitian pengembangan ini dilaksanakan di sekolah dasar yang berada di Kabupaten Merauke, Papua. Dua sekolah dasar yang dilibatkan dalam penelitian ini adalah Sekolah Dasar Mopah Lama dan Sekolah Dasar Wasur II. Subjek coba yang dilibatkan dalam penelitian dan pengembangan ini adalah siswa kelas empat dari dua kelas pada sekolah yang berbeda. Sebelum melakukan penelitian pengembangan, dilakukan prasurvey untuk mendapatkan informasi tentang kebutuhan masing-masing sekolah dasar tentang kurikulum dan pelajaran Pendidikan Jasmani. Informasi diperoleh berdasarkan observasi proses pembelajaran dan hasil wawancara terhadap guru Pendidikan Jasmani. Hasil informasi yang telah didapat selanjutnya dianalisis untuk mengetahui kebutuhan masing-masing sekolah dalam pelajaran Pendidikan Jasmani. Berdasarkan hasil observasi awal, didapatkan informasi sebagai berikut. Pertama, guru dalam mengajar di sekolah dasar menggunakan acuan Kurikulum 2013 yang berbasis 
Al-Ishlah: Jurnal Pendidikan - ISSN: $2087-9490$ (p); 2597-940X (e)

Vol. 11, No. 2 (2019)

tematik. Kesulitan guru dalam proses pembelajaran yang saling berintegrasi adalah subtema yang diajarkan pada tiap tema yang berbeda. Misalnya, pada tema lingkungan terdapat subtema mengenal dan menjaga lingkungan dari bahaya bencana alam. Pada pelajaran Pendidikan Jasmani, guru kebingungan untuk mengaplikasikannya. Kedua, Guru masih belum bisa mengajarkan sesuai arahan dari kurikulum, karena materi yang biasanya diajarkan hanyalah bermain sepak bola. Sementara itu, pada kompetensi dasar yang terdapat dalam Kurikulum 2013, di sekolah dasar harus diajarkan aktivitas jasmani di lingkungan sekolah yang mengandung nilai keselamatan. Dari cakupan permasalahan tersebut, berdasarkan hasil wawancara, guru sangat membutuhkan model yang sesuai dengan tema yang praktis dapat dipahami dan langsung diterapkan di sekolah dasar. Untuk itu, model permainan yang dibuat peneliti ini dapat menciptakan kesenangan dan ketertarikan siswa dalam melakukan gerak aktivitas jasmani yang berguna dan sesuai dengan Kurikulum 2013.

\section{Data Uji Draf Awal Produk}

Adapun spesifikasi permainan yang dikembangkan dalam bentuk model adalah sebagai berikut.

Tabel 1 Draf Model yang Dikembangkan Pada Awal Produk Beserta Indikator Pembelajarannya

\begin{tabular}{|c|c|}
\hline Nama Model Aktivitas Jasmani & $\begin{array}{l}\text { Indikator Pembelajaran } \\
\text { Tanggap Bencana }\end{array}$ \\
\hline $\begin{array}{l}\text { Model permainan aktivitas gempa } \\
\text { bumi }\end{array}$ & $\begin{array}{c}\text { Kemampuan merangkai gerakan, } \\
\text { lari menghindar, dan menuju } \\
\text { tempat berlindung }\end{array}$ \\
\hline $\begin{array}{c}\text { Model permainan aktivitas tanah } \\
\text { longsor }\end{array}$ & $\begin{array}{l}\text { Kemampuan merangkai gerakan } \\
\text { penyelamatan dari gunung }\end{array}$ \\
\hline $\begin{array}{l}\text { Model permainan aktivitas banjir } \\
\text { bandang }\end{array}$ & $\begin{array}{c}\text { Kemampuan memelihara } \\
\text { keseimbangan }\end{array}$ \\
\hline $\begin{array}{l}\text { Model permainan aktivitas evakuasi } \\
\text { titik kumpul }\end{array}$ & $\begin{array}{c}\text { Kemampuan beradaptasi dengan } \\
\text { tetap waspada dan tenang dalam } \\
\text { penyelamatan }\end{array}$ \\
\hline $\begin{array}{l}\text { Model permainan aktivitas } \\
\text { penyelamatan diri dari dalam } \\
\text { rumah/gedung }\end{array}$ & $\begin{array}{l}\text { Kemampuan menemukan dan } \\
\text { memlihara irama gerakan }\end{array}$ \\
\hline Model permainan gempa & Kemampuan mereaksi dan reaksi \\
\hline
\end{tabular}


Al-Ishlah: Jurnal Pendidikan - ISSN: $2087-9490$ (p); 2597-940X (e)

Vol. 11, No. 2 (2019)

Pada tabel di atas dijelaskan bahwa terdapat enam kegiatan adopsi aktivitas jasmani yang diasumsikan sebagai pengenalan bencana alam dan upaya yang dilakukan pada tanggap bencana. Keenam kegiatan yang dilakukan pada pemodelan perancangan model draf disesuaikan dengan aktivitas jasmani siswa dalam melakukan gerak. Jenis gerak yang dipakai pada permainan ini dibuat secara bersama-sama dan dilakukan dengan penuh keseriusan. Langkah awal yang dikembangkan berdasarkan pada: (1) analisis muatan kurikulum yang berdasar pada KI dan KD di sekolah dasar. Analisis ini bertujuan agar draf yang sudah dibuat tidak bertolak belakang dengan aturan kurikulum di sekolah dasar sehingga dapat diaplikasikan dalam pembelajaran serta tidak menyimpang dari panduan kurikulum; (2) analisis kemampuan guru dalam mengajar; (3) persiapan dan pertimbangan alat yang digunakan dalam permainan yang mudah, aman, dan dapat digunakan sesuai dengan karakter siswa. Jika draf awal yang dibuat sudah selesai, langkah selanjutnya adalah memvalidasi produk tersebut kepada ahli permainan, pendidikan jasmani, dan praktisi (yang dalam hal ini adalah guru Pendidikan Jasmani sekolah dasar). Jika para ahli sudah memberi masukan dan saran dalam pembuatan draf produk dan direvisi sesuai dengan saran ahli dan praktisi, draf sudah siap diujicobakan di lapangan.

\section{Data Uji Coba Lapangan}

Uji coba lapangan pada penelitian ini dilakukan terhadap siswa sekolah dasar kelas empat SD Mopah Lama di Kabupaten Merauke. Pelaksanaan uji coba lapangan ini dilakukan pada jam pelajaran Pendidikan Jasmani. Pada uji coba lapangan ini dilakukan pula peragaan pengenalan bencana alam yang di dalam kelas secara teoretik. Pemutaran video mengenai terjadinya bencana alam, penyebab terjadinya bencana alam, dan cara penanganan dalam menghadapi bencana alam dengan upaya tindak cepat dilakukan pula di dalam kelas. Praktik yang dilakukan dalam kegiatan uji coba lapangan ini langsung diterapkan dalam bentuk permainan. Usaha yang dilakukan dalam bentuk permainan dimaksudkan bukan sebagai bahan candaan dalam menghadapi bencana alam. Akan tetapi, melalui permainan siswa dapat melakukan gerak jasmani secara luwes dan tanpa rasa takut. Penerapan pada kegiatan uji coba lapangan ini dilakukan selama lima kali pertemuan. Hal ini dimaksudkan agar model yang memperagakan permainan ini tidak melakukan kesalahan dalam bergerak maupun memahami rangkaian gerakan yang telah diajarkan. Karena ahli yang dilibatkan tidak selalu hadir dalam rangkaian uji coba permainan ini, saat observasi dilakukan perekaman dalam bentuk video agar selajutnya dapat dilakukan validasi produk.

Peneliti selalu mendapat masukan dari para ahli setiap kali uji coba lapangan dilakukan.Masukan ini dijadikan sebagai bahan evaluasi untuk melakukan perbaikan secara bertahap. Pada pertemuan kelima, para ahli 
Al-Ishlah: Jurnal Pendidikan - ISSN: 2087-949o (p); 2597-940X (e)

Vol. 11, No. 2 (2019)

menyatakan bahwa model yang dibuat sudah sesuai dengan yang direncanakan pada draf awal produk. Adapun hasil analisis menurut ketiga ahli tersebut, model "Permainan Tanggap Bencana" yang terdiri atas enam tahap kegiatan permainan memperoleh rerata 3,6. Nilai yang diberikan ahli pendidikan jasmani (ahli satu) sebesar 3,8 terletak pada interval $X \geq 3,0$; ahli permainan (ahli dua) sebesar 3,6 terletak pada interval $X \geq 3,0$; praktisi/guru sebesar 3,5 terletak pada interval $X \geq$ 3,0. Batas nilai minimal dikatakan valid adalah 2,5. Maka, penilaian observasi model oleh ahli materi dan praktisi terhadap model "Permainan Tanggap Bencana" dikategorikan sangat baik (valid).

\section{Pembuatan Produk Final}

Penelitian dan pengembangan yang telah dilakukan pada proses ini telah mencapai tahap akhir. Pembuatan produk final dari pengembangan ini dilakukan setelah sebelumnya berulangkali mendapatkan masukan dan revisi produk. Setelah dilakukan revisi model secara menyeluruh, selanjutnya produk pengembangan yang dapat diproduksi berupa video pembelajaran dan buku panduan penggunaan model. Adapun spesifikasi produk final adalah sebagai berikut: (1) model bernama "Permainan Tanggap Bencana"; (2) isi dari model terdiri atas enam tahap kegiatan permainan, antara tahap satu dan selanjutnya mempunyai hubungan yang tidak boleh dilewatkan; (3) tahap kesatu dan kedua pada kegiatan permainan merupakan pengenalan alat dan pemahaman cara menggunakan peralatan, tahap ketiga dan keempat merupakan permainan perlombaan, serta tahap kelima dan keenam merupakan permainan yang sudah dipertandingkan. Keseluruhan rangkaian pelaksanaan permainan dapat disesuikan dengan keadaan sekolah, baik lapangan maupun peralatan permainan. Model yang sudah dibuat disimpan dalam bentuk VCD dan dapat diputar, baik sebagai pengetahuan maupun sebagai tutorial dari keanekaragaman jenis aktivitas jasmani dalam bentuk permainan.

\section{Uji Efektivitas Produk}

Produk yang sudah melalui uji coba lapangan dan mendapatkan validasi dari ahli, pada tahap selanjutnya dapat diterapkan kepada siswa. Pada penelitian dan pengembangan ini, penerapan uji efektivitas dilakukan pada Sekolah Dasar Wasur II yang berada di Kabupaten Merauke. Produk yang dihasilkan dari pengembangan yang berbentuk video tutorial dengan nama "Permainan Tanggap Bencana" diajarkan oleh guru Pendidikan Jasmani. Dalam hal ini dilakukan observasi efektivitas pembelajaran yang diukur melalui pemahaman guru dalam menerapkan model, pemahaman siswa dalam melakukan permainan, serta ketersediaan peralatan dan waktu yang sudah disesuaikan dengan jam pelajaran sekolah. Pada pertemuan awal dilakukan pengambilan data berdasarkan 
Al-Ishlah: Jurnal Pendidikan - ISSN: 2087-949o (p); 2597-940X (e)

Vol. 11, No. 2 (2019)

pemahaman guru, pemahaman siswa, jenis gerak siswa, serta alur pelaksanaan peraturan permainan tanggap bencana. Pada pertemuan terakhir juga dilakukan hal yang sama. Pelaksanaan uji efektivitas dilakukan sebanyak empat kali perlakuan. Semuanya menggunakan produk model permainan tanggap bencana. Adapun hasil dari uji efektivitas dapat dipaparkan sebagai berikut.

Tabel 2 Hasil Uji Efektifitas Melalui Eksperimen di Kelas Empat SD Wasur II

\begin{tabular}{ccc}
\hline Aspek Yang Dinilai & Nilai Gain Score & Kategori \\
\hline Pemahaman guru & 0,19 & Sedang \\
Pemahaman siswa & 0,28 & Sedang \\
Pelaksanan kegiatan permaian & 0,24 & Sedang \\
$\begin{array}{c}\text { Kesesuaian waktu yang digunakan dalam } \\
\text { menerapkan permainan tanggap bencana }\end{array}$ & 0,28 & Sedang
\end{tabular}

Dari tabel 2 di atas dapat diketahui bahwa pemahaman guru dalam menerapkan model, pemahaman siswa dalam melakukan tugas gerak aktivitas jasmani, pelaksanaan kegiatan permainan, serta kesesuaian antara waktu belajar di sekolah berada pada nilai Gain, yang masuk dalam kategori sedang.

Berdasarkan hasil penelitian dan pengembangan yang sudah dilakukan, permainan tanggap bencana efektif digunakan sebagai bagian dari pembelajaran gerak pada pembelajaran Pendidikan Jasmani di sekolah dasar. Rangkaian penelitian yang telah diupayakan pada skala kecil dan skala besar dapat direvisi dan dicarikan solusi dari kelemahan pada setiap permainan. Ketercapaian dari tiga jenis gerak, yaitu nonlokomotor, lokomotor dan, manipulatif dapat terlaksana melalui aktivitas gerak yang diadopsi dengan upaya penyelamatan diri dalam menghadapi bencana. Kesesuaian pengembangan dalam pembuatan model kegiatan aktivitas siswa dalam pelajaran Pendidikan Jasmani di sekolah dasar sangat diperlukan. Hal ini dapat diketahui dari antusiasme siswa saat melaksanakan tugas gerak dalam bentuk aktivitas jasmani. Permainan merupakan jenis kegiatan yang sangat dipahami oleh siswa dalam setiap aktivitas fisik. Melalui permainan, siswa dapat mengaktulisasikan diri dalam kegiatan praktik di lapangan. Permainan yang diadopsi dari kebutuhan gerak serta kecenderungan pengenalan jenis musibah yang ada di Indonesia efektif diajarkan pada siswa sekolah dasar. Pengenalan akan bencana alam dan cara menghadapinya dapat dilakukan melalui permainan ini. Permainan ini dapat menciptakan sikap tanggap dan antisipatif terhadap bencana alam. Pemberian pengalaman gerak sangat sesuai 
Al-Ishlah: Jurnal Pendidikan - ISSN: 2087-9490 (p); 2597-940X (e)

Vol. 11, No. 2 (2019)

diberikan kepada siswa sekolah dasar. Hal ini sesuai dengan yang diungkapkan oleh Sumarsono \& Sianturi dalam Implementation Interactive Media and Characterized Meme Media: A Comparation Study (2018) bahwa kegiatan permainan dapat digunakan sebagai pendekatan dan pemaksimalan pengalaman gerak tanpa harus mengikuti detailnya aturan. Melalui permaian, siswa dapat melakukan tugas gerak dengan tanpa keterpaksaan karena kegiatan yang menyenangkan tanpa paksaan.

\section{SIMPULAN}

Penelitian dan pengembangan yang telah dilaksanakan ini mengahasilkan dua hal yang dapat diterapkan dalam pelajaran Pendidikan Jasmani di sekolah dasar. Penelitian yang dilakukan menunjukkan ketercapaian tujuan dari pengembangan yaitu membuat model pembelajaran yang valid dan efektif dalam pembelajaran serta setelah diujicobakan dapat diterima baik oleh guru maupun murid sekolah dasar. Pengembangan yang dihasilkan adalah sebuah model pembelajaran yang sesuai dengan Kurikulum 2013. Model disimpan dalam bentuk VCD yang di dalamnya terdapat enam aktivitas permainan gerak jasmani yang diarahkan sebagai antisipasi bencana alam dan tanggap bencana. Model permainan dibuat dengan sedetail mungkin dengan mengutamakan faktor kesenangan dan keselamatan siswa saat menerapkannya. Model, setelah diujicobakan di lapangan pada sekolah yang berbeda, telah mendapatkan tanggapan positif, baik dari guru Pendidikan Jasmani maupun siswa sekolah dasar kelas empat. Berdasarkan analisis dari penerapan perhitungan Gain Score, permainan ini termasuk dalam kategori sedang.

\section{DAFTAR PUSTAKA}

Amri, A. (2017). Pedidikan Tangguh Bencana Mewujudkan Satuan Pendidikan Aman Bencana di Indonesia. Jakarta: P\&K Press.

Brockman, R., Fox, K. R., \& R, J. (2011). What is the meaning and nature of active play for today's children in the UK. International Journal of Behavioral Nutrition and Physical activity and health, Vol. 1 No. 7, 8.

Cristohper, \& Ludy. (2009). Psychology Gets in the Game: sport, mind, and behavior. Londan: Nesbraka. 
Al-Ishlah: Jurnal Pendidikan - ISSN: 2087-949o (p); 2597-940X (e)

Vol. 11, No. 2 (2019)

Dahliya, A. (2017). "Penguatan Pendidikan Karakter Melalui Kegiatan Ekstrakurikuler di sekolah. Jurnal Sosioreligi, Vol. 15 No. 1, 54.

Desfandi, M. (2014). Urgensi Kurikulum Pendidikan Kebencanaan Berbasis Kearifan Lokal di Indonesia. Sosio Didaktika: Vol. 1, No. 2.

Graham, Hale, H., \& Parker. (2009). Children moving reflective approach to teaching physical education. New York: Mc GrawHill.

I.E, E. (2014). Increasing Values of Teamwark and Responsibility of the students Through games: Integrating Education Charakter in Lectures, Journal prosedia-social nd behavioral science. Prosedia social and behavioral science, 200.

Lesmana, C., \& Purborini, N. (2015). Kesiapsiagaan Komunitas Sekolah dalam Menghadapi Bencana di Kabupaten Magelang. Jurnal Teknik Sipil Volume 11 Nomor 1.

Mantasia, \& Jaya, H. (2016). Model pembelajaran Kebencanaan Berbasis Virtual Sebagai Upaya Mitigasi dan Proses Addaptasi terhadap Bencana Alam di SMP. Jurnal Paedagogia penelitian dan pendidikan Vol. 19 No. 1.

Mardapi, D. (2008). Teknik penyusunan instrumen tes dan non tes. Yogyakarta: Mitra Cendekia Press.

Margono. (2012). Peranan Pendidikan Jasmani Menghadapi Era Globalisasi. Jurnal Media Ilmu Keolahragaan Indonesia, Vol. 2 No. 1, 62.

Mumpuniarti. (2003). Penanganan anak tuna grahita (kajian dari segi pendidikan, social-psikologis dan tindak lanjut usia dewasa. Yogyakarta: FIP UNY Press.

Perez, L. A., Pedro, Bush, \& Michael. (2013). Effects of different backpack loads in acceleration transmission during recreational distance walking . Journal of Human Kinetics, Vol. 3 No.7, 81.

Putri, $\quad$ G. $\quad$ S. $\quad(2018, \quad 12 \quad$ Rabu). https://sains.kompas.com/read/2017/12/18/214500823/kenang-kembali-7bencana-alam-terparah-di-indonesia-sepanjang2017?page=allhttps://sains. kompas.com/read/2017/12/18/214500823/ken ang-kembali-7-bencana-alam-terparah-di-indonesia-sepanjang2017?page $=$ all. Diambil kembali dari Kompas. com: 
Al-Ishlah: Jurnal Pendidikan - ISSN: 2087-949o (p); 2597-940X (e)

Vol. 11, No. 2 (2019)

https://sains.kompas.com/read/2017/12/18/214500823/kenang-kembali-7bencana-alam-terparah-di-indonesia-sepanjang-2017? page=all

Rosali, E. S. (2016). Peranan Pembelajaran Geografi dalam Pemahaman Bencana Gunung Api pada Peserta Didik SMA di Daerah Rawan Bencana Gunung Guntur. Jurnal Geografi, Volume 4 Nomor 1.

Rustiana, E. R. (2013). Upaya Peningkatan Kecerdasan Emosi Siswa Sekolah Dasar Melalui Pendidikan Jasmani Harmoni. Cakrawala Pendidikan, XXXII No. 1, 141.

Sugiyono. (2010). Metode penelitian kuantitatif, kualitatif dan $R \& D$. Bandung: Alfabeta.

Suhada, F., Khairuddin, \& Dirmansyah. (2014). Identifikasi Kesiapsiagaan Komunitas Sekolah SMA Negeri 2 Kluet Utara dalam Menghadapi Bencana Gempa Bumi dan Tsunami. Jurnal Pendidikan Kebencanaa, Volume 1, No. 2.

Suharjana. (2013). Kebugaran Jasmani. Yogyakarta: Jogja Global Media.

Sukadiyanto, \& Muluk, D. (2010). Pengantar teori dan metodologi melatih fisik. Bandung: CV. Lubuk Agung.

Sumarsono, A. (2017). Implementasi model pembelajaran atletik melalui permainan berbasis alam. Jurnal Magistra Vol. 4 No. 2.

Sumarsono, A., \& Sianturi, M. (2018). Implementation Interactive Media and Characterized Meme Media: A Comparation Study. Journal of Education and Vocational Research (ISSN 2221-2590) Vol. 9, No. 1.

Suryani, I., Sari, S. A., \& Milfayetty, S. (2014). Model Quantum Teaching dalam Meningkatkan Pengetahuan Kesiapsiagaan Bencana Gempa Bumi di Sekolah Dasar 19 Banda Aceh. Jurnal Biotik, ISSN: 2337-9812, Vol. 2, No. 2.

Susanti, R., Sari, S. A., Milfayeety, S., \& Dirmansyah. (2014). Hubungan Kebijakan, sarana dan prasarana dengan Kesiapsiagaan Komunitas Sekolah SIaga Bencana Banda Aceh. Volume 1, No. 1. 
Al-Ishlah: Jurnal Pendidikan - ISSN: 2087-949o (p); 2597-940X (e)

Vol. 11, No. 2 (2019)

Winarni, S. (2011). Pengembangan Karakter dalam Olahraga dan Pendidikan Jasmani. Cakrawala Pendidikan, XXX Edisi Khusus Dies Natalis UNY, 127. 